DOI: https://doi.org/10.47405/aswj.v6i1.142

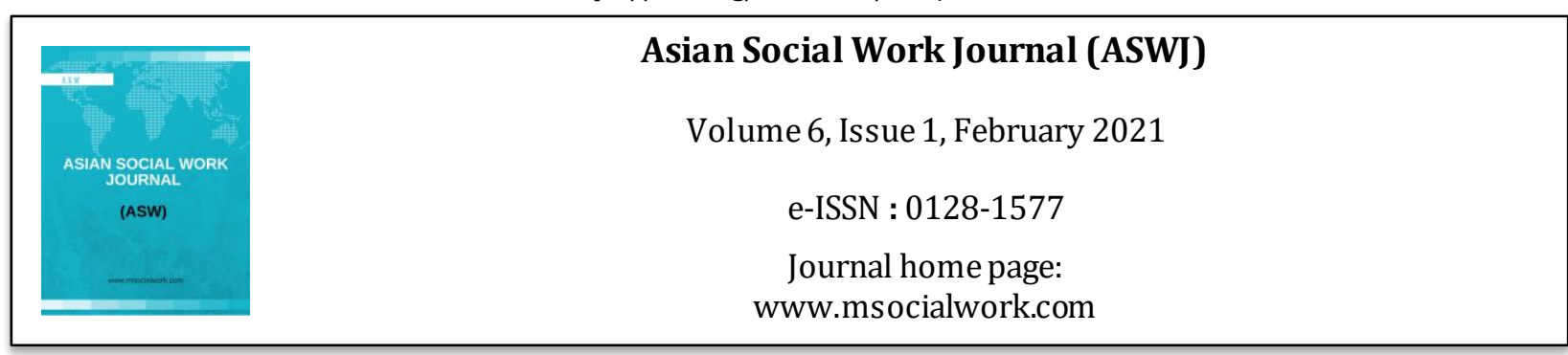

\title{
Strategy and Society: Corporate Social Responsibility (CSR) to the Revolving Fund Program
}

\author{
Windhi Tia Saputra', Yul Tito Permadhy², Fitria Ayuningtyas ${ }^{1}$, Niken Ridianti1 \\ ${ }^{1}$ Department of Communication, Faculty of Social and Political Sciences, \\ Universitas Pembangunan Nasional Veteran Jakarta, Indonesia \\ ${ }^{2}$ Department of Business and Management, Faculty of Economics and Management, \\ Universitas Pembangunan Nasional Veteran Jakarta, Indonesia \\ Correspondence: Fitria Ayuningtyas (fitria.irwanto@upnvj.ac.id)
}

\begin{abstract}
This research was conducted to evaluate the Implementation of Corporate Social Responsibility (CSR) in the existing education program at PT FIFGROUP, as a program to help improve SME entrepreneurs' quality of business located around the company, especially in Cilandak Sub-district, South Jakarta. The theory used in this research is Corporate Social Responsibility. The method used in this research is qualitative, a case study approached, and the type of research descriptive. The data collection technique is in-depth interviews with Key Informant and Informants as well as methods of data validity by source. The results obtained in this research used the stages of Corporate Social Responsibility (CSR). The results of program activities have been running well by its purpose and benefits. The conclusion of the results of this research indicated that MSME entrepreneurs (micro, small and medium enterprises) got helped by the revolving fund program as assistance in improving the business. It is implemented by the stage of the implementation of Corporate Social Responsibility (CSR) and PT FIFGROUP doing continuous improvement to spread revolving funds to SME entrepreneurs (micro, small and medium enterprises) that eligible and promptly.
\end{abstract}

Keywords: Corporate Social Responsibility (CRS), small and medium enterprises, revolving, fund

\section{Introduction}

In this era, business competition is growing rapidly. Society has to take strategic steps to compete with any conditions and or any competitor. In addition to demands for competitiveness, the community must also have an advantage that can distinguish for better quality. Nowadays, the organization must innovate to improve their quality.

Over the last four decades, the world's major attention has been focused on ways to accelerate the rate of economic growth (Roser, 2016). Every economist in a rich and emerging country uses the capitalist, socialist, or both of them really want and always makes economic growth one of their priorities. Nowadays, growth rapidly is the central theme of every economical life in every country. The success of development programs in third world countries is often judged on the high level of growth of output and national income (Crook, 1992).

All developing countries such as Indonesia, although among them relatively rich while others are relatively poor. Like other developing countries, the majority of these countries, especially the poor, 
DOI: https://doi.org/10.47405/aswj.v6i1.142

face a difficult problem. One of the issues is macro-economic imbalances reflected on unemployment, and high inflation, a very large balance of payments deficit, depreciation of a continuing currency exchange rate and heavy debt burden, and income and wealth gaps are very wide between the different groups from each country. Today, in facing a high need that always increases, many societies in Indonesia build an SME business or small and medium enterprises. The concept from small and medium enterprises (SME) is different from one country to another.

The development strategy for financing and the empowerment of SMEs in Indonesia is very rapidly growing. The growth and role of SMEs are predicted to increase in the Indonesian economy. With the optimism of change and the role of SMEs and the improvement potential for credit financing from banks, it is necessary to formulate and describe the implementation of clear strategies and programs to achieve them, namely what support can be done by the government, Bank Indonesia, banking and nonbank financial institutions, the business world and society in general, so that SMEs can truly become the main pillars of the economy (Fitriasari, 2017).

The definition of 'Small and Medium Enterprises' under Indonesian law differs from the generally accepted definition of 'Small and Medium Enterprises (UKM-Usaha Kecil dan Menengah)'. The country's description of 'Small and Medium Enterprises' was set out in the Small Enterprise Act No. 9 of 1995 (UNDANG UNDANG REPUBLIK INDONESIA NOMOR 9 TAHUN 1995 TENTANG USAHA $K E C I L$ ), where companies that would generally be considered medium-sized are included under the definition for "small enterprises" and the purpose for "medium enterprises" under Indonesian law roughly equates to the Japanese meaning of "medium enterprises" (Ministry of State Owned Enterprises, 2008).

The Central Statistics Agency classifies medium-sized enterprises and industries in three ways, microenterprises with household industries made up of three employees or less (including non-paid laborers), small enterprises consisting of 5-9 employees, and medium enterprises consisting of 20-99 employees (Ministry of State Owned Enterprises, 2008). SMEs play an important role in economic growth and social inclusion in Indonesia. Based on data from the Ministry of Co-operatives and SMEs, Indonesian SMEs account for nearly 97\% of domestic employment and 56\% of total business investment. Indonesia has a Micro, Small, and Medium Enterprise (MSME) Law and a specific ministry dedicated to cooperatives and SMEs (OECD, 2018).

According to Indonesia Investment (2016), The Minister of Finance of Indonesia, Sri Mulyani Indrawati, emphasizes the importance of cooperation between the government and Indonesia's micro, small and medium enterprises (including startups). Indrawati spoke at the 12th World Islamic Economic Forum (WIEF) that opened on Tuesday (02/08/16) in Jakarta. In her speech, Indrawati stated that Indonesia's micro, small, and medium-sized enterprises are the Indonesian economy's backbone. These enterprises account for $99 \%$ of the total number of enterprises operating in Indonesia and create 107.6 million jobs in Southeast Asia's largest economy. Moreover, Indonesia's micro, small, and medium-sized companies contribute $60.6 \%$ to Indonesia's gross domestic product (GDP). All these facts indicate the importance of the existence of these companies. They cushion the country's economy in times of shocks. However, most of these companies do not pay taxes, while most workers belong to the informal sector (Rajesh, 2016).

In Indonesia, there are different concepts of SME, depending on who defines it. The Ministry of Industry and Trade of Indonesia determined that the scale of SME enterprises is divided into micro industries (1-4 workers), small industries (5-19 workers), and medium industries (20-99 workers) stated by Sule \& Saefullah (2005). The Department of cooperatives small and medium enterprises based on data from BisInfocus, divide SME into three groups based on their total assets, total annual sales, and business status of micro, small and medium enterprises (Fitriasari, 2017).

The main obstacle is poverty. Although the government requires 12 years of education with free tuition fees, easy access to scholarship, poverty still made many families decide not to send their children to school. This problem could be understood considering that sending their children to school 
DOI: https://doi.org/10.47405/aswj.v6i1.142

doesn't only mean paying the tuition fee but also paying their uniforms, transport, allowance, and other school charges.

One of the most dependable efforts of the middle to low society is small and medium-sized microenterprises. Micro, small and medium enterprises (MSME) have a strategic role in national economic development. The SME, commonly known as small and medium enterprises, refers to a type of business established by a person and has a net worth of IDR 200.000.000,00 (not including land and buildings) (Nayla, 2014).

In the economic crisis that occurred in Indonesia since not so long time ago, that make stagnated and even stopped its activities for big business companies, moreover for Small and Medium Enterprises sector (SME) that more resilient face that crisis. Considering the situation that ever happened with Indonesia, it is not excessive if private sector development is focused on MSME (micro, small and medium enterprises). Moreover, this business unit is often neglected only because of its small scale production and not yet able to compete with other business units. Indonesia's high unemployment rate is also one reason why economic growth in this country is difficult to compete with other developed countries because of low education, low information, and skills that make them not want to start a new business and improve their quality of life.

According to some problems mentioned before, we could conclude that Indonesian society's economy becomes one of the most important to see how rapidly Indonesia's country can improve or even grow. PT Federal International Finance (FIF) is a finance company wholly owned by Astra. FIF's business is initially focused on conventional and sharia financing to support retail sales of Honda motorcycles. Subsequently, FIF developed used motorcycle financing and SPEKTRA, a new credit product for general consumer goods, including household electronics and appliances.

One of the main priorities FIF work program was the intensification of the distribution network by focusing on product and operational enhancements through synergies and cross-functional relationships with business partners, including parties that are integrated within the business networks of Astra Group, Honda Sales Operation, automotive dealerships, and other functional networks, among others joint financing. Product innovation, such as the SPEKTRA card, is designed to expand further and diversify the customer base. FIF also undertook focused marketing programs and improved its internal surveillance ability to properly monitor changes in the industry to be used as the basis for internal alignment with external conditions to win over the competition.

This economic society's growth becomes one of the main focus of Corporate Social Responsibility PT FIFGROUP's program to help micro, small and medium organizations build their MSME business towards a better life or help society itself open or start a micro, small and medium-sized enterprise.

Corporate Social Responsibility itself is a concept or action undertaken by the company as a sense of corporate responsibility to the social and the environment around which the company is located, such as doing an activity that can improve the welfare of the surrounding community and maintain the ground, give a scholarship, funds for the maintenance of public facilities, donations to build village/community facilities that are social and useful to the public, especially the society around that company environment.

Corporate Social Responsibility activities undertaken by PT FIFGROUP in realizing a wellestablished Indonesia society in the economy are supported through a revolving fund program to assist the organization in improving MSME business or starting a new location. This program is given to all MSME entrepreneurs who start a business or create a new place. FIFGROUP's CSR is always trying to assist MSME entrepreneurs with this revolving fund program.

Researchers take this economic empowerment with revolving fund programs because this program will give fund lending to MSME entrepreneurs in two steps every year. This program has become a priority than other programs that are only implemented periodically. This revolving fund program tended to always continue with CSR Cilandak sub-district until the next step. 
Implementation of community development by the company, called social mapping, was held to see and know the condition that happened with the society around its operational place. The company will do need assessment or find the needs of the community to realize it.

FIFGROUP presented to accommodate the diversity of needs in Indonesia by always holding with innovation and creativity principles. "Turning a challenge into opportunities" is based thinking that makes FIFGROUP still grow in FIFGROUP's profile company.

Due to that matter, in 2017, PT FIFGROUP re-organized the Corporate Social Responsibility revolving fund program for SME entrepreneurs in the Cilandak sub-district. That fund lending could be installment every next month without interest. They were hoping that all SME entrepreneurs could increase their business model or start their new business with this fund lending. Therefore, MSME entrepreneurs could directly feel the impact of this revolving fund program.

Based on the explanation above, the researchers would like to research the title below: "Strategy and Society: Corporate Social Responsibility to the Revolving Fund Program."

\section{Literature Review}

\section{Corporate SocialResponsibility (CSR)}

The responsibility of a company or Corporate Social Responsibility (CSR) based on the World Business Council on Sustainable Development (WBCSD) is a company's commitment to do behavioral ethics and contribute to sustainable economic development. Other obligations are to improve the quality of employees and their family life, local community, and society. Harmonization between a company and organization around them will be achieved if there is a full commitment from its top management with CSR as public accountability (Effendi, 2016).

Corporate social responsibility (CSR) is believed to improve a company's reputation. However, CSR may also put reputation at risk by making the company a more attractive target for activists' campaigns (Graafland, 2018).

According to Kotler, CSR is discretionary, which means something that must be done. If the company does not do CSR, it will harm itself. CSR is still not a required rule (in Indonesia, it has been through a corporation). According to the World Business Council for Sustainable Development, CSR is not just discretionary, but a commitment for a company to make a better quality of life. Philosophically, if the company always tries to be useful to humanity, it will certainly exist (Rahman, Effendi, \& Wicaksana, 2011).

The prevailing approaches to CSR are so disconnected from business as to obscure many of the greatest opportunities for companies to benefit society (Porter \& Kramer, 2006).

\section{Corporate Social Responsibility Planning Steps}

CSR planning steps divided into 4 (four) parts (Wibisono, 2007):

\section{Planning Step}

Planning steps consist of three main stages: awareness building, CSR assessment, and CSR manual building. Awareness building is a first step to build awareness about how important CSR and management commitment are. This effort can be done with the conference, so on. CSR Assessment is an effort to map the company's condition and identify every aspect that needs attention, priority, and the right steps to build a conducive company structure to apply for CSR programs. The next step is to 
DOI: https://doi.org/10.47405/aswj.v6i1.142

construct manual CSR. The result from the assessment is a basic manual preparation or CSR implementation guidelines.

\section{Implementation Step}

The implementation step consists of three stages. There are socialization, implementation, and internalization. Socialization is required to introduce all the company components related to every aspect of CSR, specifically CSR implementation guidelines. This socialization's main purpose is to make a CSR program that will be implemented to get full support from all components of that company. The implementation of this program basically should be working based on CSR guidelines. Meanwhile, internalization is a long-term step. Internalization includes every effort to introduce CSR inside the entire business process, such as using management systems.

a. Evaluation Step. After the CSR program is implemented, the next step is the evaluation program. Evaluation is a step that needed to be done consistently from time to time to measure CSR program implementation effectiveness.

b. Reporting is required to build a great information system for the process to get the right decisionmaking or the openness from relevant material information related to the company.

\section{Community Development}

Community development is a social development that is systematically planned and directed to reach high access, to get social conditions, economic and better life quality in society than before, based on Budimanta (2002). Essentially, community development is a social culture adaptation conducted by industry, central government, and sub-regions in local community life (Rudito \& Famiola, 2013).

Figure 1: Corporate Social Responsibility's STEP in FIFGROUP

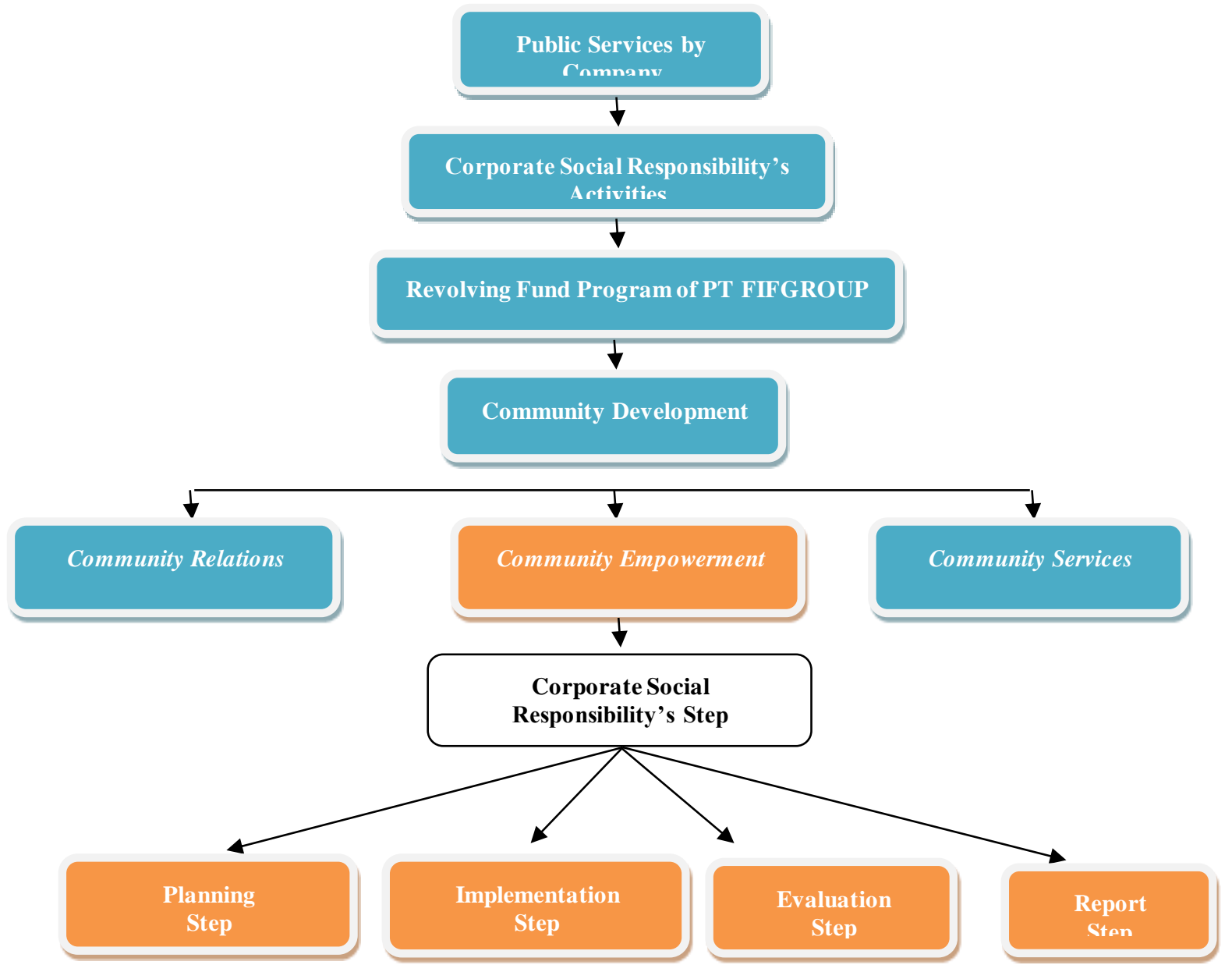

Source: Researchers’ Documentation 
DOI: https://doi.org/10.47405/aswj.v6i1.142

\section{PDCA (Plan, Do, Check, and Action)}

PLAN: organization plan related to what they have to do to supply the customers with products or services.

DO: on the next step, the organization must do what it has been planned before on the first step.

CHECK: the organization has to check and notice that everything has been done well and comply with customers' requirements.

ACTION: then, the organization makes appropriate changes (if needed), so it will comply with the requirements on the next time.

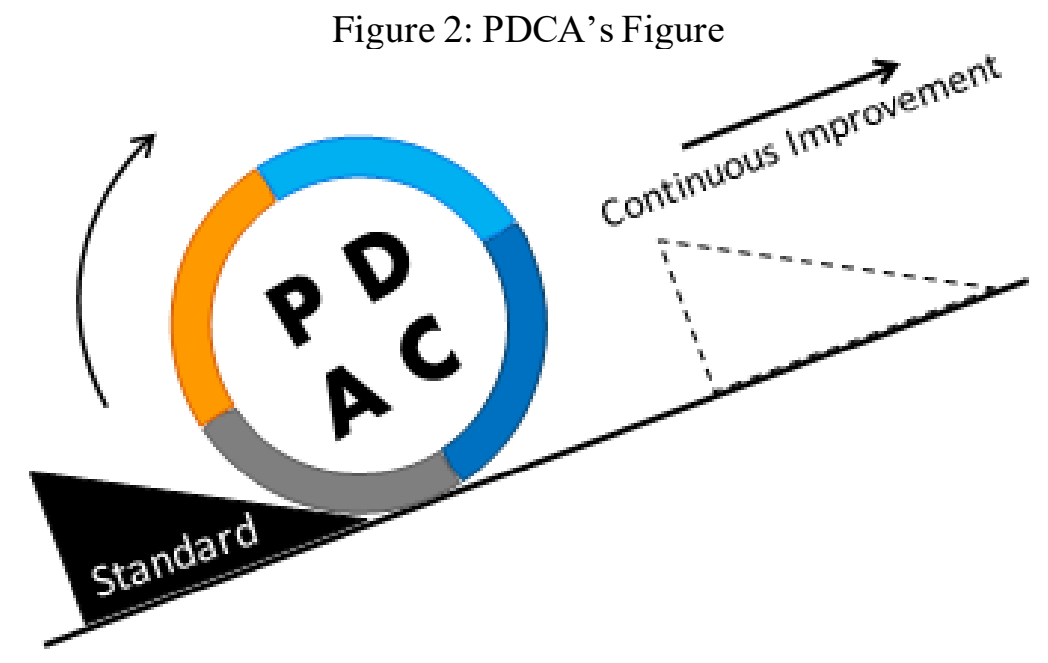

Source: (CIToolKit, 2018)

The PDCA Cycle is a framework for problem-solving, continuous improvement, and change. It is widely recognized as the basis of continually improving the quality of processes, products, and services. It is easy to remember four logical sequence steps: Plan, Do, Check, and Act. It provides a simple and structured approach to solving quality-related problems. Multiple iterations of the PDCA cycle may be necessary to solve the problem and reach the ultimate goal state permanently.

The PDCA cycle is particularly effective when intending to make minor changes to a process and when the problem is known. It allows us to verify a proposed idea's feasibility, whether it is an incremental or a breakthrough improvement. Repeating the PDCA cycle will help implement Kaizen and other continuous improvement initiatives. Additionally, TQM, the ISO standards, and the A3 thinking process are all based around the PDCA philosophy.

Using the PDCA cycle encourages the methodical way of problem-solving and implementing solutions. It ensures that you plan, test, and incorporates feedback before you start full-scale implementation. PDCA brings you closer to your goals as knowledge is increased from solving problems, failures, and feedback. It also improves your team's critical thinking skills and helps your organization reach a more integrated system.

The economic system in Indonesia, SME, is a business group with a large number and has been proved resistant to all financial crisis varieties. The business criteria which is included in SME have been regulated in law. Based on Constitution No 20, 2008, some measures were used to define small and medium enterprises. According to Rahmana (2008), some institutions or agency have their definition on small and medium enterprises, some of the institutions are the ministry of state cooperation and small-medium enterprises, central bureau of statistics, minister of finance's policy Number 
316/KMK.016/1994, June 27, 1994. The definition of small and medium enterprises are different from one and another (Sudaryanto, 2011).

Figure 3: PDCA's Diagram

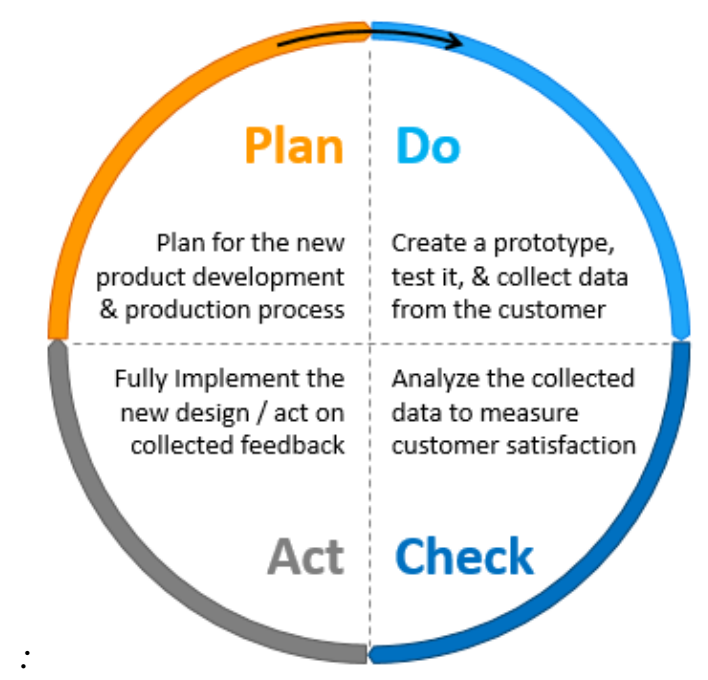

Source: (CIToolKit, 2018)

\section{Methods}

Denzin \& Lincoln (1998) qualitative is an emphasis on the process and a meaning that is not being tested or measured exactly in terms of quantity, the numbers, intensity, or frequency. The qualitative researcher emphasizes the nature of reality in social construction, intimate relations between researchers and what they learned, and situational obstacles that form inquiry (Ahmadi, 2014).

The qualitative research will answer the problem formulations and the purpose of the research. The CSR of PT FIFGROUP to SME entrepreneurs at the Cilandak sub-district as the subject of this research. Data collecting technique on that qualitative research are:

a. Interview. An interview is one of the techniques that could be used for collecting data for research. A simple interview can be said as the interaction between the interviewer and the interviewee through direct communication. The interviews were conducted to Mr. Kinalso Tarigan as Department Head of FIFGROUP's CSR and three entrepreneurs who received revolving fund programs, Mr. Taufiq, Mr. Satrio, and Mr. Irwanto.

b.

c. Documentation. Documentation is a record or work of a person about something in the past. Document about person, group, or event in social information related to the research's main focus is a very useful information source (Yusuf, 2014). This research is obtained through company history, research journal, company magazine, picture, and story.

Qualitative research is a type of research whose findings are not obtained through the statistical procedure or another calculation form. It has the purpose of exposing the symptoms holistic-contextual through collecting data from natural backgrounds use researches as key instruments. Qualitative research is descriptive and tends to use analysis with an inductive approach - process and significance based on a highlighted perspective on qualitative research (Sugiarto, 2015).

\section{Data Analysis Technique}

Bogdan \& Brklen (1982) stated that data analysis is the process of systematically searching and arranging the interview transcripts, field notes, and other materials that you accumulate to increase 
DOI: https://doi.org/10.47405/aswj.v6i1.142

your understanding of them and enable you to present what you have discovered to others (Yusuf, 2014).

\section{Data Validity Techniques}

Triangulation with the source information means comparing and re-check trusted levels of knowledge gained through different times and tools in qualitative research, stated by Patton (1987) (Moleong, 2009).

The method conducted on this research uses the triangulation method through deep interview towards key informant and informant, direct observation to all SME entrepreneurs after all the data sources have been collected. It will analyze again with the theory related to this research. By analyzing the data source, we will conclude this research.

\section{Results and Discussion}

According to most people, the Indonesian economy is currently free from the impact of the monetary crisis, but economic development tends to stagnate as indicated by the low growth rate and the lower level of welfare of the majority of the population. Inequality of production and income among community groups is no longer visible because the productivity of this nation is very low and large businesses are not developing as in the New Order Era.

But on the other side, the development strategy for financing and the empowerment of SMEs in Indonesia is very rapidly growing. The growth and role of SMEs are predicted to increase in the Indonesian economy. With the optimism of change and the role of SMEs and the improvement potential for credit financing from banks, it is necessary to formulate and describe the implementation of clear strategies and programs to achieve them, namely what support can be done by the government, Bank Indonesia, banking and non-bank financial institutions, the business world and society in general, so that SMEs can truly become the main pillars of the economy (Fitriasari, 2017).

The definition of 'Small and Medium Enterprises' under Indonesian law differs from the generally accepted definition of 'Small and Medium Enterprises (UKM-Usaha Kecil dan Menengah)'. The country's description of 'Small and Medium Enterprises' was set out in the Small Enterprise Act No. 9 of 1995 (UNDANG UNDANG REPUBLIK INDONESIA NOMOR 9 TAHUN 1995 TENTANG USAHA $K E C I L$ ), where companies that would generally be considered medium-sized are included under the definition for "small enterprises" and the purpose for "medium enterprises" under Indonesian law roughly equates to the Japanese meaning of "medium enterprises" (Ministry of State Owned Enterprises, 2008).

In the economic crisis that occurred in Indonesia since not so long time ago, that make stagnated and even stopped its activities for big business companies, moreover for Small and Medium Enterprises sector (SME) that more resilient face that crisis. Considering the situation that ever happened with Indonesia, it is not excessive if private sector development is focused on MSME (micro, small and medium enterprises). Moreover, this business unit is often neglected only because of its small scale production and not yet able to compete with other business units. Indonesia's high unemployment rate is also one reason why economic growth in this country is difficult to compete with other developed countries because of low education, low information, and skills that make them not want to start a new business and improve their quality of life.

According to some problems mentioned before, we could conclude that Indonesian society's economy becomes one of the most important to see how rapidly the country of Indonesia can improve or even grow. PT Federal International Finance (FIF) is a finance company wholly owned by Astra. FIF's business is initially focused on conventional and sharia financing to support retail sales of Honda motorcycles. Subsequently, FIF developed used motorcycle financing and SPEKTRA, a new credit product for general consumer goods, including household electronics and appliances. 
One of the main priorities FIF work program was the intensification of the distribution network by focusing on product and operational enhancements through synergies and cross-functional relationships with business partners, including parties that are integrated within the business networks of Astra Group, Honda Sales Operation, automotive dealerships, and other functional networks, among others joint financing. Product innovation, such as the SPEKTRA card, is designed to expand further and diversify the customer base. FIF also undertook focused marketing programs and improved its internal surveillance ability to properly monitor changes in the industry to be used as the basis for internal alignment with external conditions to win over the competition.

FIFGROUP's Corporate Social Responsibility implementation role on make and give revolving fund program for SME entrepreneurs at Cilandak sub-district through some steps. The first step that FIFGROUP's CSR did was social mapping. Social mapping is the activity to get information related to the problem, potential, and society needed (social, cultural, economic, and political). However, the purpose of social mapping is more than that. Similar to Chamber et al. (2003) defined CSR as being social action (including environmental), beyond companies' legal requirements. Although it was traditionally assumed that CSR was somehow beyond the company's immediate profit-making activity, this criterion is hard to maintain in the context of the increasing development of the business case for CSR (Chambers, Chapple, Moon, \& Sullivan, 2003).

The purpose of social mapping is to get to know how society realizes the problem they have to face. Society realizes their potential and understands what they need. FIFGROUP's CSR mapping society's social needs, and from that result, we could get the conclusion to determine what society needs. FIFGROUP's CSR makes a list of what is required during the planning step on that program. The second step is implementation. This step is to arrange the program evenly and in detail. Preparation of the program strategy discussion with FIFGROUP's CSR team and the directors also discussed the programs that will be implemented and gain approval in a running activity. Inside the implementation making step, FIFGROUP's CSR usually applied the PDCA concept or Plan, Do, Check, and Action.

The PDCA cycle begins with a Planning phase, where the problem and objectives are identified. In Planning, the team selects the problem to be solved (or the process to be improved) to deliver results by the expected goals. In Planning, you analyze the current situation, identify solution alternatives, and select and schedule the most promising solution. The solution is then tested on a small scale basis in the Do phase. Do involves implementing the solution on a small scale, collecting data for later analysis, and measuring progress. To ensure the solution is appropriately tested and benefits are validated before committing to full implementation.

The check involves analyzing the collected data and comparing the actual results against the planned objectives. It allows evaluating how well the solution worked and discussing whether further improvements are possible. It is also concerned with identifying the unexpected issues, their causes, and gathering and summarizing the key learnings. Note that you may need to repeat the Do and Check some times until you get the optimum results.

A plan should be created for the full implementation after evaluating the costs and benefits for each alternative. The act involves acting on the feedback and lessons learned and implementing the solution fully. The act is also concerned with standardizing, documenting, sustaining the improved process, and integrating it into its system.

The use of the PDCA Cycle doesn't necessarily stop here. Once the Act phase has been completed, you may identify the next improvement target and start again at the planning phase. The PDCA cycle can be repeatedly applied in continuous improvement where there is no end to it. Each cycle will bring you closer to your goals and will extend your knowledge further. Data should be collected continuously to measure and evaluate the performance continually.

This concept explained the implementation step in a program that needs to arrange program planning, explained how CSR activities implement, and evaluates the program that will be implemented. The 
DOI: https://doi.org/10.47405/aswj.v6i1.142

third step from FIFGROUP's CSR is evaluation. On this step, FIFGROUP's CSR does review a long assessment of the activities undertaken; this case is for noticing and knowing if the program is already appropriated with the purpose or not. Also, to detect whether all plans have been executed, according to the goal, the benefits delivered well, according to the budget (cost), the program's time of implementation, and the target. The last step is the reporter's step. On this step, FIFGROUP's CSR team has been doing recapitulation against the evaluation program, and then it will enter into the reporting step. Reporting usually takes two weeks after the program has been done. All the review reports or evaluations toward the program accounted for by FIFGROUP's CSR department. The information from the revolving fund program already appropriated the target.

SME entrepreneurs (micro, small and medium enterprises) got helped by the revolving fund program as assistance in improving the business, it is implemented by the stage of the implementation of Corporate Social Responsibility (CSR) and PT FIFGROUP doing continuous improvement to spread revolving fund to SME entrepreneurs (micro, small and medium enterprises) that eligible and promptly.

\section{Conclusion}

In this research, researchers would like to know how FIFGROUP's CSR program's implementation on the pillar of society's economic empowerment. CSR FIFGROUP's Revolving fund program is a program made to help the community needed, especially around FIFGRUOP's company. This revolving fund program is a modal loan program for SME entrepreneurs. This program has the purpose of helping SME entrepreneurs and could be used for additional business models or to start a new business. The target of this program is the Cilandak sub-district society, especially SME entrepreneurs. Social mapping aims to get to know how the community realizes the problem they have to face. They recognize their potential and understand what they need. FIFGROUP's CSR mapping society's social needs, and from that result, we could get the conclusion to determine what the company needs. FIFGROUP's CSR makes a list of what is required during the planning step on that program. This research indicated that SME entrepreneurs (micro, small and medium enterprises) got helped by the revolving fund program as assistance in improving the business, it is implemented by the stage of the implementation of Corporate Social Responsibility (CSR) and PT FIFGROUP doing continuous improvement to spread revolving fund to SME entrepreneurs (micro, small and medium enterprises) that eligible and promptly.

\section{Acknowledgment}

The authors would like to thank all those who participated in this research and express gratitude to Universitas Pembangunan Nasional Veteran Jakarta, Indonesia, especially the Faculty of Social and Political Sciences and FIF Group Management.

\section{References}

Ahmadi, R. (2014). Metodologi Penelitian Kualitatif. Yogyakarta: Ar-Ruzzmedia.

Chambers, E., Chapple, W., Moon, J., \& Sullivan, M. (2003). CSR in Asia : A seven country study of CSR website reporting. ICCSR Research Paper Series, 44(09), 1-43.

CIToolKit. (2018). Plan, Do, Check, Act. Retrieved from https://citoolkit.com/articles/pdca-cycle/

Crook, C. (1992). The Concise Encyclopedia of Economics. Third World Economic Development. Retrieved September 13, 2018, from https://www.econlib.org/library/Enc1/ThirdWorldEconomicDevelopment.html

Effendi, M. (2016). The power of good corporate governance: teori dan implementasi (Edisi 2). Jakarta: Salemba $\quad$ Empat. $\quad$ Retrieved from http://www.library.usd.ac.id/web/index.php?pilih=search\&p=1\&q=0000135410\&go=Detail

Fitriasari, Fi. (2017). Strategi Pengembangan Pembiayaan Usaha Mikro Kecil dan Menengah 
DOI: https://doi.org/10.47405/aswj.v6i1.142

(UMKM) di Indonesia. Universitas Muhammadiyah Malang Proceeding, (August), 133-149. https://doi.org/10.13140/RG.2.2.26869.88801

Graafland, J. (2018). Does Corporate Social Responsibility Put Reputation at Risk by Inviting Activist Targeting? An Empirical Test among European SMEs. Corporate Social Responsibility and Environmental Management, 25(1), 1-13. https://doi.org/10.1002/csr.1422

Ministry of State Owned Enterprises. (2008). SMEs in Indonesia. Retrieved September 4, 2020, from http://www.dcmsme.gov.in/Policies/highlights_of_internatinal_policies/Indonesia Policy.pdf

Moleong, L. (2009). Metodologi Penelitian Kualitatif (Edisi Revisi). Bandung: Remaja Rosdakarya.

Nayla, A. (2014). Komplet Akuntansi Untuk UKM dan Waralaba. Yogyakarta: Laksana.

OECD. (2018). SME and Entrepreneurship Policy in Indonesia 2018. Retrieved from http://www.oecd.org/publications/sme-and-entrepreneurship-policy-in-indonesia-20189789264306264-en.htm

Porter, M., \& Kramer, M. (2006). Strategy \& Society: The Link between Competitive Advantage and CSR. In Harvard Business Review (pp. 1-14). US A: FSG.

Rahman, N., Effendi, A., \& Wicaksana, E. (2011). Panduan Lengkap Perencanaan CSR. Jakarta: Penebar Swadaya.

Rajesh, E. K. (2016). Indonesia Investment. Retrieved from https://www.indonesiainvestments.com/id/news/todays-headlines/indonesian-economy-micro-small-medium-sizedenterprises/item7068

Roser, M. (2016). Economic Growth. England. Retrieved from https://ourworldindata.org/economicgrowth

Rudito, B., \& Famiola, M. (2013). CSR. Bandung: Penerbit Rekayasa Sains.

Sudaryanto, R. (2011). Strategi Pemberdayaan UMKM Menghadapi Pasar Bebas ASEAN. Yogyakarta: Kedaulatan Rakyat.

Sugiarto, E. (2015). Menyusun Proposal Penelitian Kualitatif Skripsi dan Tesis. Yogyakarta: Suaka Media.

Wibisono, Y. (2007). Membedah Konsep dan Aplikasi CSR. Gresik: Fascho Publishing.

Yusuf, A. (2014). Metode Penelitian Kuantitatif Kualitatif dan Penelitian Gabungan. Jakarta: Prenadamedia Group. 